\title{
SUMMER SESSION OF COLUMBIA UNIVERSITY
}

The following extracts are from the "Summer School Commencement of Columbia University" for the prescnt summer. Of the many courses given for general students, three are of special importanee to nurses-thosc on chemistry, domestic science, and physical education, a synopsis of which courses we print below. The course "Chemistry sr $3 a$ " is especially instructive to nurses interested in artificial feeding of infants, "Domcstic Science si $4 b$ " to those studying thc questions of houschold foods and supplies, while the work in "Physical Education" must appeal to all.

Any nurse who could arrange to attend the Summer Sehool this July and August would he well repaid for her time and expense by the freshening of her gencral professional knowledge and the opening of new avenues of thought and study.

\section{COLUMBIA UNIVERSITY IN THE CITY OF NEW YORK- SUMMER SCHOOL ANNOUNCEMENT}

The sixth Summer Scssion of Columbia University will open on Thursday, July 6, 1905, and eontinue until Thursday, August 17, inelusive.

Each course will consist of a minimum of thirty leetures or other exercises, or thicir equivalent in laboratory or field work.

cost.

1 -Registration fee ............................ $\$ 5.00$

2-Tuition fee (for one, two, or three courses) .............. 30.00

It is believed that the total expense involved in attendance upon the Summer Session, ineluding tuition fee, but excluding railroad fare, may readily be kept below eighty-five dollars. In no cvent need it exceed one hundred dollars.

BOARD AND LODGING.

Whittier Hall, a University residence located at 1230 Amsterdam Avenue, between One-Hundred-and-Twentieth and One-Hundred-andTwenty-first Streets, will be open for the accommodation of the students of the Summer Session.

A special rate of fifty dollars is made for the students of the Summer Session, from dinner on Wednesday, July 5 , to breakfast on Friday, August 18, inclusive. This rate is payable in advance and includes room, board, and laundry (one dozen plain pieces per week). 


\section{CHEMISTRY.}

sF-Chemistry of nutrition. Five hours lectures and collateral reading. Dr. ShermaN.

1.30, Room 511, Havemeyer.

This course prerequires a knowledge of elementary organic chemistry and deals mainly with the functions of the proteids, fats, and carbohydrates in nutrition and the analytical and experimental methods by which the quantitative composition and nutritive values of foods are determined. It includes a critical study of the methods and results of recent investigations in food chemistry and human nutrition.

This course may be taken with $\mathrm{sr}_{3} a$, with s2o, or any of the courses in domestic science given at Teachers Collegc.

sr $3 a$-Proximate organic and sanitary analysis. Conferences and laboratory work, fifteen to thirty hours a werk. Dr. Strrerman. 2.30, Room 509, Havemeyer.

The work in this course nnay be selectel. according to the time and nceds of the student, from among the following subjects: the quantitative analysis of foods and the physiological products; artificial digestion experiments; the preparation and analysis of modified milk; the determination of heat of combustion by the bomb calorimeter; any of the organic or sanitary analyses included in Course 13 (see Announcement of the Division of Chemistry).

Public lecture, August 8-Dr. Sherman.

Milk: production, preservation, and properties. (Illustrated.)

\section{DOMESTIC SCIENCE}

ss $2 b$-Food production and manufacture. Lectures, reading, and excursions. Professor VulTE.

9.30, Room 401, Teachers Collegc.

A course describing the treatment that crudc foods undergo before they reach the consumer, including methods of refining, sterilizing, etc., the manufacturing processes used in producing the bettcr-known types of prepared, predigested, and substituted foods. Discussion of the economic value of the various products. During the scssion of 1905 the following topics will be treated: milk and its products, creain, butter, cleese, etc., butterine and olcomargerine, eggs and egg powders, meats and fish, both fresh and preserved, tea, coffee, cocoa, and chocolate, baking powders.

Continued from the Summer Session of 1904. Students who elect it may complete the first half in the Summer Session of 1906. 
sI $4 b$-Household chemistry. Lectures, reading, and laboratory work. Professor Vulte.

10.30-12.20, Room 401, Teachers College.

A systematic course of instruction on the more important foods, their composition, and the changes which take place during the processes of cookery. Discussion of cooking processes and comparison of results, with the view of choosing the best methods, special attention being given to loss of nutritive value.

Special topics for 1905: bread, cereals, milk, butter, cheese, fats, tea, coffee, cocoa, chocolate, and baking powders. Testing of soaps, detergents, and bleaches, with special reference to their utility. Composition of cooking utensils, cause and prevention of corrosion due to food or improper care. Simple tests for common adulterants and preservatives.

Students who have had the equivalent of this course will be given the opportunity to pursue advanced studies in the chemistry of foods and stimulants in the laboratory.

Laboratory fee, five dollars.

Continued from the Summer Session of 1904. Students who elect it may complete the first half in the Summer Session of 1906.

PHYSICAL EDUCATION.

83-Personal hygiene and first aid to the injured. Lectures and practical work. Professor MEYLAN.

\subsection{0, Thompson Building.}

This course considers personal health as a problem in vital eco. nomics; the human body as an organic machine and the aim of personal hygiene to be the provision of the most efficient body mechanism for the life-needs of the individual. The topics include the argument for the careful study of health and hygiene; ideals of health influencing differcnt peoples; structure and functions of the human body; changes in the organism due to evolution and civilization and the health problems arising from these changes; conditions necessary to the perfect state of the body and the activity of the various functions; causes of weakness, injury, degeneration, and disease; improvement of health and prevention of disease by hygienic means; methods of first aid to the injured.

sio-Applied anatomy and physiology. Lectures, demonstrations, and quizzes. Dr. Sharstrom.

\subsection{0, Thompson Building.}

This course is intended for beginners and those who have not had the advantages of a normal school of physical training. The subjects of anatomy and physiology will be treated from the standpoint of physical education. The course will deal with the structure and functions of the tissues and organs in the human body; mechanism of movement; influence of motor activity on the various organs and functions of the body. 
si3-Anthropometry, diagnosis, and prescription of corrective exercises. Lectures and practical work. Professor MEYLAN.

8.30, Thompson Building.

This course deals with the practical methods of studying the human organism; of determining its conditions and needs, and of applying the various measures indicated for normal development, improvement of health and strength, correction of deformities, prevention and cure of certain forms of disease. The course includes the following: recording of personal and family history; measuring and testing the body; observation of organic conditions and physieal signs; theory and tabulation of statisties; use of graphic methods for representing bodily conditions and changes; individual preseription of exercise and hygienic regimen, corrective exercise for eommon deformities, such as round shoulders and spinal curvature; adaptation of movements for functional disorders and special nervous conditions. There will be practical work for all students.

\section{SCHOOL FOR SOCIAL WORKERS}

\section{MAINTAINED BY SIMMONS COLLEGE AND HARVARD UNIVERSITY}

TOPICS INCLUDED IN TIIE COURSE OF STUDY

Aim of Social Srrvice.-Right conceptions of social duty-The interdependence of men-The worker-Preparation and purpose. Leading principles underlying all social effort: Investigation the basis of constructive work-Knowledge of standards of living, of neighorhood needs and resources-Individual treatment of individuals-The family and ties of kinship-Effect on neighbors and the community-Conference, and coöperation in a plan-Economy of adequate relief-Recording of experience.

Improvement of General Conditions of Living.-Community action: Sanitary measures-Housing legislation-Recreation-Hygiene of occupation-Protection of children from premature work-Limitations of legislation. Voluntary action: Private experiment looking to government action-Coöperative associations-Improved housing-Industrial betterment.

Neighborhood Improvement in City and Codntry.-Organization of local responsibility-Social work of the local church-Settlements and neighborhood guilds-Coöperation with local public administration - Higher standards of home life and friendly acquaintance-Physical, industrial, and domestic training.

Scope of Charitr.-Motives and methods-Causes of dependency - Public aid and private charity-The church and the needy-Organization of charity. 